\title{
Characterization and application of monoclonal antibodies against white spot syndrome virus
}

\author{
H H Shih, C S Wang, L F Tan and S N Chen \\ Department of Zoology, National Taiwan University, Taipei, Taiwan, ROC
}

\begin{abstract}
Three hybridoma clones secreting monoclonal antibodies (MAbs) were produced from mouse myeloma and spleen cells immunized with white spot syndrome virus (WSSV) isolated and purified from Penaeus monodon (Fabricius), collected from north-eastern Taiwan. By sodium dodecyl sulphate-polyacrylamide gel electrophoresis (SDSPAGE), the protein profile of this isolate contained four major proteins with sizes of approximately 35 (VP35), 28 (VP28), 24 (VP24), and $19 \mathrm{kDa}$ (VP19). Western blot analysis revealed that two MAbs (1D7 and 6E1) recognized epitopes on VP28 and one MAb (3E8) recognized an epitope on VP19. The MAb 6E1 isotyped to the $\mathrm{IgG}_{1}$ class was used in both an indirect immunofluorescence assay (IFA) and in an immunochemical staining protocol for successful identification and localization of WSSV in infected shrimp tissues. Antigenic similarity of isolates from Indonesia and Malaysia to the Taiwan isolate was illustrated by IFA with MAb 6E1. A MAb (2F6) which bound specifically to two shrimp proteins, 75 and $72 \mathrm{kDa}$, and reacted to the healthy and non-target tissues of WSSV in infected shrimp, such as hepatopancreas, is also described here and shows the necessity for specific identification of antibodies.
\end{abstract}

Keywords: diagnosis, MAbs, Penaeus monodon, white spot syndrome virus, WSSV, IFA.

Correspondence H H Shih, Department of Zoology, National Taiwan University, Taipei, Taiwan 106, ROC (e-mail: shihhh@ccms.ntu.edu.tw)

\section{Introduction}

White-spot disease, caused by white spot syndrome virus (WSSV), is a relatively recent but widespread epizootic of cultured shrimp in Asia. This epizootic probably began in Taiwan in 1992 (Chen 1995) and subsequently spread to most shrimp growing countries in Asia (Flegel \& Alday-Sanz 1998), and to the south-eastern United States (Nunan, Poulos $\&$ Lightner 1998). The disease has occurred naturally in cultured penaeid shrimp such as Penaeus chinensis (Zhan, Yu \& Meng 1995), P. japonicus (Inouye, Miwa, Oseko, Nakano, Kumura, Momoyama \& Hiraoka 1994), P. monodon (Chou, Huang, Wang, Chiang \& Lo 1995) and has been produced experimentally in $P$. vannamei, $P$. stylirostris (Durand, Lightner, Nunan, Redman, Mrai $\&$ Bonami 1996) and P. monodon (Kanchanaphum, Wongteerasupaya, Sitidilokratana, Boonsaeng, Panyim, Tassanakajon, Withyachumnarnkul \& Flegel 1998). Recently the virus was observed in wild Metapenaeus ensis in Taiwan (Wang, Tsai, Kou \& Chen 1997) and in other crustaceans (Lo, Ho, Peng, Chen, Hsu, Chiu, Chang, Liu, Su, Wang \& Kou 1996a).

Because of the devastation WSSV has caused in affected shrimp farms various detection methods have been developed to help monitor and control its spread. The most extensively used protocols are based on the polymerase chain reaction (PCR) technique (Kimura, Yamano, Nakano, Momoyama, Hiraoka \& Inouye 1996; Lo, Leu, Ho, Chen, Peng, Chen \& Chou 1996b). The DNA-based hybridization methods have also been reported (Durand et al. 1996; Chang, Tsai \& Wang 1998). These techniques are highly sensitive and allow for detection of WSSV in asymptomatic animals. 
Immunological diagnostic methods have also been exploited. A Western blot protocol for the specific and early detection of Chinese baculovirus (CBV) in experimentally infected shrimps as well as WSSV-infected primary shrimp cell cultures was developed using polyclonal antibodies prepared in rabbits (Nadala, Tapay, Cao \& Loh 1997). A nitrocellulose-enzyme immunoblot (NC-EIB) method was used to detect the presence of systemic ectodermal and mesodermal baculovirus (SEMBV) in various tissues of infected $P$. monodon. Furthermore, polyclonal antiserum raised against a prominent viral protein $(27 \mathrm{kDa})$ in mice was successfully used to detect SEMBV in shrimp by NC-EIB and competitive enzyme-linked immunosorbent assay (ELISA) techniques (Hameed, Anilkumar, Raj \& Jayaraman 1998). With the development of hybridoma technology, a panel of monoclonal antibodies (MAbs) was produced and used in an indirect immunofluorescence assay (IFA) for rapid diagnosis of WSSV (Zhan, Wang, Fryer, Okubo, Fukuda, Yu \& Meng 1999).

In the present paper, the production and characterization of another panel of MAbs against WSSV is described. After analysis by Western blot, a MAb (MAb 6E1) identified to be specific for a VP28 envelope protein was used to develop a specific IFA and an immunochemical staining protocol for WSSV detection in tissue sections. In addition, we assessed its usefulness for investigating the antigenic relationships of three WSSV isolates from Asia, using IFA.

\section{Materials and methods}

\section{Virus purification}

Samples of moribund $P$. monodon were collected from shrimp farms in north-eastern Taiwan. The samples were examined by gross anatomy and PCR for confirmation of the disease using a protocol described previously (Wang et al. 1997). To purify the virus, gill and head soft tissues were harvested from infected shrimps. The tissues were suspended in TNE buffer $(50 \mathrm{~mm}$ Tris, $100 \mathrm{~mm} \mathrm{NaCl}, 1 \mathrm{~mm}$ EDTA, $\mathrm{pH} 7.4$ ) at $10 \% \mathrm{w} / \mathrm{v}$ and homogenized manually in an ice bath. Virus purification was carried out as described by Takahashi, Itami, Maeda, Suzuki, Kasornchandra, Supamattaya, Khongpradit, Boonyaratpalin, Kondo, Kawai, Kusuda, Hirono \& Aoki (1996), with modification. Tissue debris was pelleted at $3000 \mathrm{~g}$ for $10 \mathrm{~min}$. The supernatant was filtered

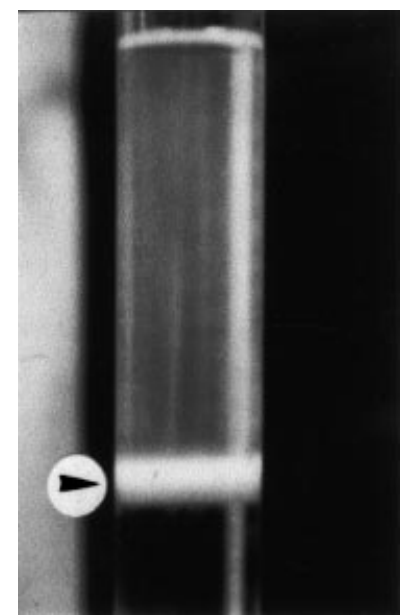

Figure 1 The band of concentrated WSSV virions formed in the sucrose discontinuous density gradient. Arrowhead indicates the virus band.

through a $0.45-\mu \mathrm{m}$ membrane. The filtrate was ultracentrifuged at $100000 \mathrm{~g}$ for $1 \mathrm{~h}$ at $4^{\circ}$ (Hitachi $85 \mathrm{H} 2$, RPS40T rotor, Tokyo, Japan). The pellet was then soaked in a small volume of TNE buffer at $4^{\circ}$ overnight. The pellet was gently resuspended and the suspension was layered onto the top of a discontinuous gradient of 10 and $50 \%(\mathrm{w} / \mathrm{v})$ sucrose and then ultracentrifuged at $100000 \mathrm{~g}$ for $1 \mathrm{~h}$ at $4^{\circ}$. A single virus band was observed at the interface between the 10 and $50 \%$ sucrose solutions (Fig. 1) and harvested with a Pasteur pipette. The virions were washed with TNE buffer by ultracentrifugation at $100000 \mathrm{~g}$ for $1 \mathrm{~h}$ at $4^{\circ}$. The virus preparation was assayed for protein concentration by Bio-Rad protein assay kit and used for mouse immunizations, ELISA, sodium dodecyl sulphate-polyacrylamide gel electrophoresis (SDS-PAGE), and Western blot.

\section{Immunization}

Balb/c strain mice were immunized with the virus preparation $\left(25 \mu \mathrm{g}\right.$ mouse $\left.^{-1}\right)$ emulsified in Freund's complete adjuvant. Starting 3 weeks after the first immunization, booster injections of antigen in incomplete adjuvant were given twice at 2 -week intervals. The mice were killed 3 days after the last injection.

\section{Fusion}

Spleen cells from immunized mice were fused with P3-X63-Ag8U1 myeloma cells in 50\% (w/v) 
polyethylene glycol 1500 (Merck, NJ, USA). Fused cells were resuspended in RPMI1640 medium (Flow Laboratories Inc., VA, USA) supplemented with $20 \%$ foetal bovine serum (FBS) and hypoxanthineaminopterine-thymidine (HAT) (GIBCO-BRL, NY, USA) and plated into 96-well culture plates. After 2 weeks of selection in HAT medium, hybridomas were screened for antibody production by ELISA. The cells from wells showing positive reactions were cloned twice by limiting dilution. The MAb preparations used in the following studies were unpurified cell culture supernatants from these hybridomas.

\section{ELISA}

The 96-well EIA plates (Nunc, Denmark) were coated overnight at $4^{\circ}$ with $100 \mu \mathrm{L}$ well ${ }^{-1}$ of the virus preparation diluted to $1 \mu \mathrm{g} \mathrm{mL}^{-1}$ in carbonate buffer ( $50 \mathrm{~mm}, \mathrm{pH}$ 9.6). The plates were then washed three times in phosphate buffered saline (PBS) with $0.1 \%$ Tween 20 (PBS-T) followed by blocking with $3 \%$ bovine serum albumin (BSA) in PBS-T, $100 \mu \mathrm{L} \mathrm{mL}^{-1}$, for $1 \mathrm{~h}$ at room temperature. All subsequent incubations were performed at $37^{\circ}$. The plates were drained and incubated for $1 \mathrm{~h}$ with $100 \mu \mathrm{L}$ well ${ }^{-1}$ of the hybridoma supernatants to be examined. Serum from the mouse that was used for the fusion served as the positive control, and the conditional media pooled from myeloma cell culture, P3-X63-Ag8U1, was used as the negative control. After washing the plates three times in PBS-T, $100 \mu \mathrm{L}$ well ${ }^{-1}$ of peroxidaseconjugated goat anti-mouse Ig (Kirkegaard \& Perry Laboratories, Inc., Gaithersburg, MD, USA), $1 / 2000$ in PBS-T, was added and the plates were incubated for a further $1 \mathrm{~h}$. Finally, following washing, $100 \mu \mathrm{L}$ well ${ }^{-1}$ of $\mathrm{H}_{2} \mathrm{O}_{2}-\mathrm{OPD}$ substrate (3.5 mM o-phenylenediamine and $0.012 \%$ hydrogen peroxide in $35 \mathrm{~mm}$ citrate $/ 150 \mathrm{~mm}$ phosphate, $\mathrm{pH}$ 5.0) was added. The optical density was read at $492 \mathrm{~nm}$ using an ELISA reader (DigiScan, ASYHITECH, Austria) after $30 \mathrm{~min}$ incubation. In initial screening, a hybridoma supernatant was regarded as ELISA-positive when its absorbance value was above 1.0 , which was 20 times higher than that of the negative control wells.

Monodon-type baculovirus (MBV), purified from shrimp hepatopancreas as described previously (Chang, Wang, Lo, Kou \& Chen 1992), was also coated $\left(0.1 \mu \mathrm{g}\right.$ well $\left.^{-1}\right)$ in EIA plates (Nunc) as the control antigen to determine the specificity of the MAbs produced. In this second screening, a hybridoma supernatant was regarded as WSSVspecific when its absorbance value was above 0.5 in the WSSV-coated well, provided that the absorbance of the corresponding well coated with control antigen, MBV, did not exceed $10 \%$ of the value of the WSSV antigen.

\section{SDS-PAGE}

The structural proteins of the virus were analysed by $12.5 \%$ SDS-PAGE according to the method of Laemmli (1970). Samples were electrophoresed for $90 \mathrm{~min}$ at $100 \mathrm{~V}$ and the gels stained using a silver stain kit (Amersham Pharmacia Biotech, Uppsala, Sweden). Molecular weight standards were coelectrophoresed.

\section{Western blotting}

The unstained, electrophoresed gel was blotted onto a nitrocellulose membrane in blotting buffer $(3.03 \mathrm{~g}$ Tris base, $14.4 \mathrm{~g}$ glycine, and $200 \mathrm{~mL}$ methanol $\mathrm{L}^{-1}$ ) at $100 \mathrm{~V}$ for $1 \mathrm{~h}$. The membrane was then rinsed in TBS buffer (20 mm Tris- $\mathrm{HCl}, 137 \mathrm{~mm}$ $\mathrm{NaCl}, \mathrm{pH} 7.5$ ), soaked in 5\% skim milk (in TBS) for $1 \mathrm{~h}$, and rinsed again in TBS for $5 \mathrm{~min}$. The membrane was treated with hybridoma culture fluids as the primary antibody for $1 \mathrm{~h}$, rinsed three times with TBS for $5 \mathrm{~min}$, and then treated with 1:4000 dilution of the secondary antibody (peroxidase-conjugated goat anti-mouse Ig, KPL) for $1 \mathrm{~h}$. The membrane was again rinsed three times with TBS for $5 \mathrm{~min}$ and then treated with the $3,3^{\prime}, 5,5^{\prime}$ tetramethylbenzidine (TMB) membrane peroxidase substrate (KPL) until the bluish purple colour developed. The membrane was soaking in distilled water to stop the reaction and air-dried. All of the incubations were carried out at room temperature.

\section{Isotype determination}

Monoclonal antibody class and subclass were determined by using the MAb-based mouse Ig isotyping kit (PharMingen International, San Diego, CA, USA) according to the protocol recommended by the manufacturer.

\section{Immunofluorescence assay}

The cephalothorax of naturally diseased shrimp was treated in Davidson's fixative for $48 \mathrm{~h}$. The specimens were then processed routinely for 
histology. Paraffin embedded sections $6-7 \mu \mathrm{m}$ in thickness were rehydrated through graded alcohol (3 min each in $100,80,40$, and $20 \%$ ethanol) to water. The slides were fixed in cold acetone for 20 min and rinsed with PBS. They were then incubated in blocking solution ( $5 \%$ skim milk/PBS) for $1 \mathrm{~h}$ at room temperature. The slides were then covered with hybridoma culture fluids as primary antibody. After incubation for $1 \mathrm{~h}$ at $37^{\circ}$ in a humidified chamber, the slides were rinsed three times for $5 \mathrm{~min}$ with PBS. The secondary antibody, fluorescein isothiocyanate-conjugated goat antimouse Ig (1:200 in $1 \%$ skim milk/PBS)(KPL), was applied at $37^{\circ}$ for $1 \mathrm{~h}$. The preparations were rinsed again with $\mathrm{PBS}$, mounted in glycerol and examined using fluorescence microscopy.

To compare the antigenicity of geographic isolates of WSSV, the cephalothorax of infected shrimps collected from Indonesia and Malaysia were also assayed with IFA.

\section{Immunochemical staining}

Deparaffinized sections were fixed and rehydrated followed the procedures described above. The endogenous peroxidase activity of tested tissues was blocked by immersion of the slides into an extra blocking solution $\left(0.3 \% \quad \mathrm{H}_{2} \mathrm{O}_{2} / 100 \%\right.$ methanol $)$ for $30 \mathrm{~min}$. After rinsing in distilled water for $5 \mathrm{~min}$ and soaking in PBS for $10 \mathrm{~min}$, the slides were incubated with a serum block solution (10\% normal goat serum/PBS) for $20 \mathrm{~min}$ to minimize the background reaction. The slides were then covered with hybridoma culture fluids as the first antibody and incubated for $1 \mathrm{~h}$ at $37^{\circ}$. A secondary antibody, peroxidase-conjugated goat anti-mouse Ig $(1: 200$ in PBS)(KPL), was applied onto these slides. After 60 -min incubation at $37^{\circ}$, the slides were washed and treated with a TrueBlue peroxidase substrate (KPL) containing TMB and $\mathrm{H}_{2} \mathrm{O}_{2}$ for $10 \mathrm{~min}$. They were rinsed in distilled water for $1 \mathrm{~min}$, and counter-stained with $1 \%$ of aqueous eosin for $1 \mathrm{~min}$. The slides were rinsed again with distilled water, mounted in glycerol, and examined under the light microscope to identify the positive nuclei stained blue to purple.

\section{Results}

Two trials were conducted to obtain hybridoma clones secreting MAbs against WSSV. Fourteen days after fusion, approximately $90 \%$ of the 576
Table 1 Detection of hybridomas secreting monoclonal antibodies and their specificity by ELISA, immunoglobulin class or subclass, and their epitopes

\begin{tabular}{|c|c|c|c|c|}
\hline \multirow[b]{2}{*}{ MAb } & \multirow{2}{*}{$\begin{array}{l}\text { Class or } \\
\text { subclass }\end{array}$} & \multicolumn{3}{|c|}{ ELISA $\left(\mathrm{OD}_{492}\right)$ to } \\
\hline & & WSSV* $^{*}$ & MBV & Western blot; \\
\hline 1D7 & $\lg G_{1, \kappa}$ & $2.52 \pm 0.21$ & $<0.03$ & VP28 \\
\hline $2 F 6$ & $\lg \mathrm{M}_{\kappa}$ & $1.88 \pm 0.29$ & $<0.05$ & RS \\
\hline 3E8 & $\lg \mathrm{M}_{\kappa}$ & $1.87 \pm 0.32$ & $<0.04$ & VP19 \\
\hline 6E1 & $\lg G_{1, \kappa}$ & $2.98 \pm 0.15$ & $<0.05$ & VP28 \\
\hline
\end{tabular}

${ }^{*}$ Mean \pm SD of three individual tests.

$\uparrow$ Western blot: VP28 = epitope on the envelope structural protein of WSSV with a molecular mass of $28 \mathrm{kDa}$; VP19 = epitope on the envelope structural protein of WSSV with a molecular mass of $19 \mathrm{kDa}$;

$\mathrm{RS}=$ reaction with shrimp-origin proteins with molecular masses of 75 and $72 \mathrm{kDa}$.

seeded wells contained hybridomas. In the initial ELISA screening assay, approximately $30 \%$ of the hybridomas gave strong positive reactions with purified WSSV. Some of the strongest ELISApositive hybridomas were selected for subcloning by limiting dilution. Subcultivation and subsequent screening by ELISA yielded 20 positive hybridoma clones and four representative clones are described in Table 1. Specificity of these MAbs was tested with a second agent, MBV. Indirect ELISA using MBV as antigen showed that none of these four MAbs reacted with MBV (Table 1).

Isotype determination showed that MAb 1D7 and $6 \mathrm{E} 1$ were $\operatorname{IgG} \mathrm{G}_{1}$ with a $\kappa$ light chain. The other two MAbs, 2F6 and 3E8, were IgM with a $\kappa$ light chain (Table 1).

After separation by SDS-PAGE, more than 20 bands were observed in the WSSV extract. Six major proteins were identified with an apparent molecular mass of $75,72,35,28$ (VP28), 24 (VP24) and $19 \mathrm{kDa}$ (VP19), respectively (Fig. 2A). The 75 and $72 \mathrm{kDa}$ bands are shrimp proteins copurified with the virions (van Hulten, Westenberg, Goodall \& Vlak 2000).

The Western blot analysis illustrated the binding ability of MAbs 1D7 and 6E1 to VP28 (Fig. 2B, lane 1), and MAb 3E8 to VP19 (Fig. 2B, lane 2). One representative (MAb 2F6) with binding ability to both the 75 and $72 \mathrm{kDa}$ proteins is shown in Fig. 2B, lane 3. The MAb 6E1 was subsequently applied in IFA and immunochemical staining to detect WSSV in diseased shrimp.

Using MAb 6E1 in IFA, nuclei exhibiting positive reactions for WSSV were located in gill epithelial cells (Fig. 3A) and in the stomach epidermis (Fig. 3B). Circulating haemocyte 


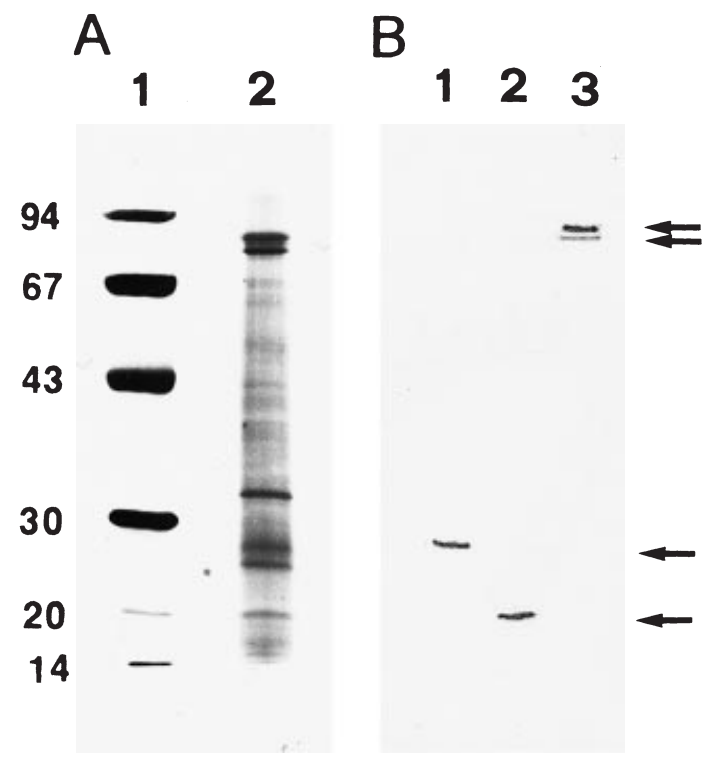

Figure 2 Western blot and SDS-PAGE of purified WSSV Taiwan isolate. (A) $12.5 \%$ of silver-stained gel; lane 1: Bio-Rad low molecular weight marker; lane 2: purified Taiwan isolate. (B) Western blot of Taiwan isolate using MAbs; lane 1: MAb 6E1 binding to viral envelope protein VP28; lane 2: MAb 3E8 binding to another viral envelope protein VP19; lane 3: MAb $2 \mathrm{~F} 6$ binding to shrimp-origin proteins, 75 and $72 \mathrm{kDa}$ (arrows).

aggregates (Fig. 3C) or haemocytes fixed amongst the striated skeletal muscles also showed positive reactions (Fig. 3D). Background fluorescence was only observed in healthy shrimp tissue, such as gill (Fig. 3E). In contrast, MAb 2F6 specific to shrimp proteins $(75$ and $72 \mathrm{kDa})$ reacted to healthy shrimp hepatopancreas (Fig. 3F).

In addition, MAb 6E1 also detected WSSV in various tissues collected from Indonesian and Malaysian shrimp, although the strength of positive reactions were different compared with the Taiwan isolate (Table 2). Strong fluorescence was observed in stomach epidermis of a sample from Indonesia, but a comparatively weak reaction was shown in gill epithelium of the Malaysian samples.

Immunochemical staining, using MAb 6E1, clearly distinguished infected and uninfected cells in the various tissues tested, including gill epithelium and lymphoid organ. Infected cells with clearly hypertrophied nuclei gave positive signals when stained by MAb 6E1 (Fig. 4A,B). Although the positive signal in immunochemical staining was primarily nuclear, a positive signal was also evident in the cytoplasm. The normal nuclei in healthy cephalothoracic epidermis showed no reactions (Fig. 4C).

\section{Discussion}

Previous characterizations of the structural proteins of WSSV and other related viruses show that they consist of a complex protein profile, and that at least three dominant polypeptides, 27.5, 23.5 and $19 \mathrm{kDa}$, are present in the WSSV virion (Nadala, Tapay \& Loh 1998; Nadala \& Loh 1998; Hameed et al. 1998). Three dominant polypeptides with similar sizes $(25,23$ and $19 \mathrm{kDa})$ have also been detected in six geographic isolates of WSSV from China, India, Thailand, as well as three locations in the USA (Wang, Poulos \& Lightner 2000). Furthermore, van Hulten et al. (2000) observed four major proteins in the same size range with approximate masses of 19 (VP19), 24 (VP24), 26 (VP26) and $28 \mathrm{kDa}$ (VP28), respectively. According to these authors two proteins, VP24 and VP26, are the major components of the WSSV nucleocapsid. Two other major virion proteins, VP19 and VP28, are most likely constituents of the virion envelope. A complex protein composition of the Taiwan isolate is indicated by SDS-PAGE analysis in the present study. Four major and several less prominent protein bands were observed. The sizes of the three major virion proteins, i.e. VP19, VP24 and VP28, were the same as those described by van Hulten et al. (2000) (Fig. 2A). In our study VP26 was not detected, but a $35-\mathrm{kDa}$ major band was observed. This band has only so far been identified in a Taiwanese isolate.

Three other major protein bands in the range of 67-78 kDa have been detected in shrimp haemolymph and copurified with the virions (van Hulten et al. 2000). Two proteins within this size range, 75 and $72 \mathrm{kDa}$, were found in this study (Fig. 2A). As these two proteins were usually copurified with the viral preparation, MAbs specific to them were selected by ELISA using a WSSV preparation as the antigen. It is, therefore, most important to ensure specificity of antibodies (polyclonal or monoclonal) produced against the viral preparation prior to detection of specific WSSV proteins. The use of identified MAbs in immunodiagnostic protocols will significantly improve their specificity.

The IFA and an immunochemical staining method, using MAb 6E1, clearly localized WSSV in infected shrimp sections. Strong labelling was limited to infected nuclei and was stronger when there was hypertrophy of the nucleus in the immunochemical staining assay (Fig. 4). Infection 

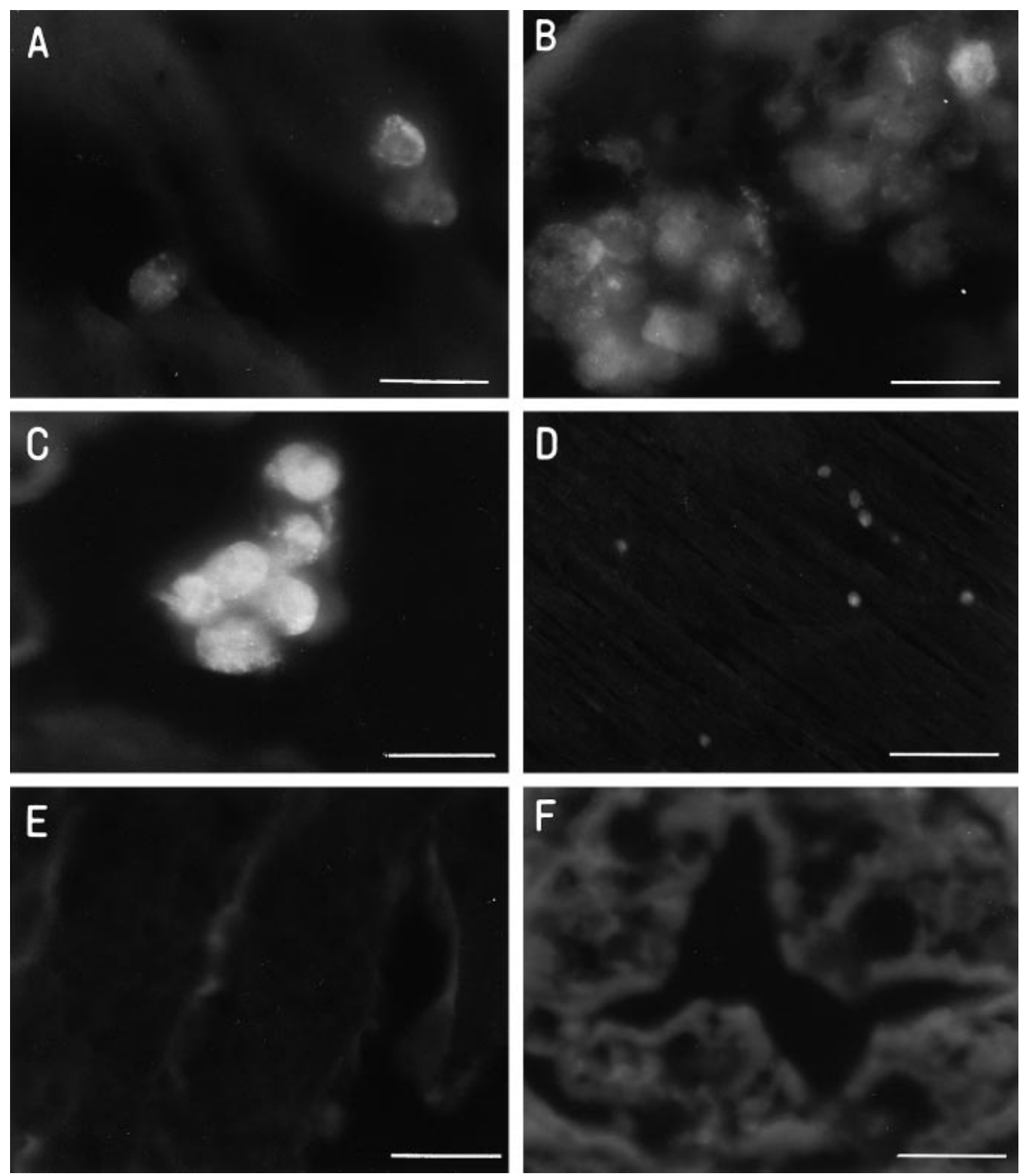

Figure 3 Immunofluorescence assays. Paraffin wax sections of the cephalothorax were prepared from WSSV-infected and uninfected shrimps. Anti-WSSV MAb (6E1) shows positive reactions with the gill epithelial cells (A), the epidermis of the stomach (B), circulating haemocyte aggregates $(\mathrm{C})$, and fixed haemocytes amongst the striated muscle fibres (D) of infected shrimp, but negative reaction with the gill tissue of healthy shrimp (E). Another MAb (2F6) specific to shrimp-origin proteins reacted uniformly with healthy uninfected hepatopancreatocytes (F) [bars $=25 \mu \mathrm{m}$ in (A, B, C, E, F), $100 \mu \mathrm{m}$ in (D)].

was detected in gills, epidermis, haemocytes, lymphoid organ and the stomach. The target tissues for WSSV detected by MAb 6E1 are the same as those reported by Chen (1995) and Inouye et al. (1994). No positive reaction was found in healthy shrimp tissue, such as gills (Fig. 3E), or uninfected epidermis cells under the cephalothoracic cuticle (Fig. 4C).

A major envelope protein of WSSV and related viruses, VP28, has been detected in various geographic isolates including CBV from China (Nadala et al. 1997; Nadala \& Loh 1998), white-spot virus 
Table 2 Detection of WSSV-infections in diseased shrimp from three geographic locations by indirect IFA using MAb 6E1

\begin{tabular}{llll}
\hline & \multicolumn{2}{l}{ Tissue examined } \\
\cline { 2 - 4 } WSSV & Gill & $\begin{array}{l}\text { Stomach } \\
\text { epidermis }\end{array}$ & Haemocytes \\
isolate & epithelium & +++ & +++ \\
\hline Taiwan & ++ & +++ & ++ \\
Indonesia & ++ & ND & ++ \\
Malaysia & + & ++ \\
\hline
\end{tabular}

+++ = strong fluorescence; $++=$ moderate fluorescence; + = weak fluorescence.

ND: Not done.

(WSV) from Indonesia and the USA (Nadala \& Loh 1998), SEMBV from India (Hameed et al. 1998), and WSSV from Thailand (van Hulten $e$ al. 2000), India, China and the USA (Wang et al. 2000). In this study, it was also detected in a Taiwanese isolate and isolates from Indonesia and Malaysia. This result confirms and expands the observation that seven different geographical WSSV isolates from clinical samples (collected from China, India, two from Thailand and three from the USA) were genetically closely related based on dot hybridization data and the restriction fragment length polymorphism (RFLP) analysis of PCR products (Lo, Hsu, Tsai, Ho, Peng, Kou \& Lightner 1999). Nadala \& Loh (1998) showed that three isolates of WSV from the USA, Indonesia and China were antigenically identical by Western blot using polyclonal antiserum. The present study highlights the antigenic relatedness of WSSV isolates from Taiwan, Indonesia and Malaysia, using a MAb recognizing an epitope on a single viral structural protein, VP28.

Immunological, as well as nucleic acid hybridization detection assays often suffer from poor specificity, especially when tissue extracts or biological fluids are used. This is mainly because of either cross-reactions with non-target proteins (ELISA, NC-EIA, capture-ELISA) or nucleic acids (hybridizations) or simply non-specific molecular interactions (Nadala et al. 1997). With the development of hybridoma technology, a method has become available for producing more specific immunological reagents. The MAbs generated in this study have strong binding activity for WSSV but not for MBV, another virulent virus of penaeid shrimp. One MAb (6E1) described, locates WSSV successfully in infected target tissues by IFA and immunochemical staining. Further-
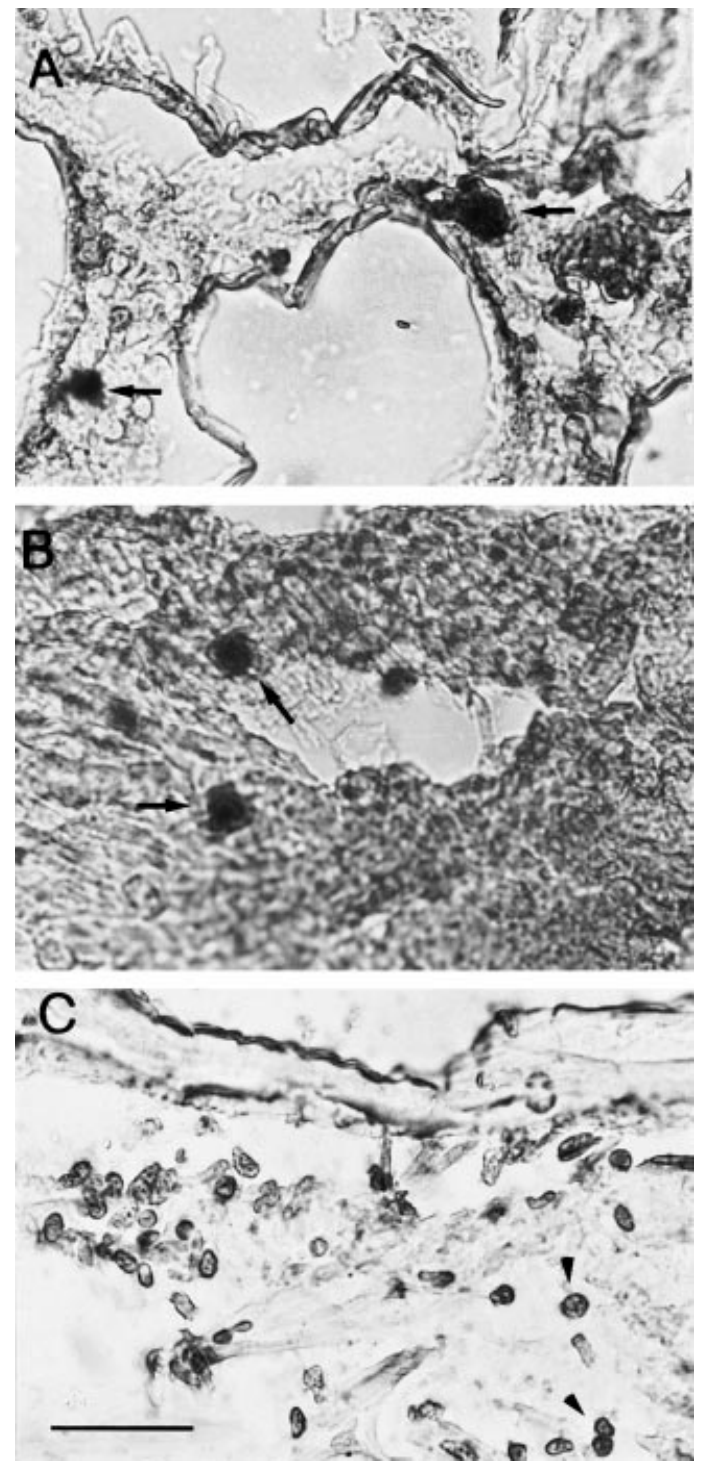

Figure 4 Detection of WSSV-infected nuclei in P. monodon by immunochemical staining with MAb 6E1. Hypertrophied nuclei in the infected gill (A) and lymphoid organ (B) show darkstaining positive signals (arrows). The normal nuclei in healthy cephalothoracic epidermis (C) show no reaction (arrowheads) (bar $=25 \mu \mathrm{m}$ ).

more, it has for the first time enabled assessment of the degree of antigenic similarity between WSSV isolates based on a single epitope located on the viral envelope protein VP28. These results strongly suggest that MAb 6E1 is useful for diagnosis of WSSV infections and gives useful information for the classification of WSSV isolates and related viruses. 


\section{Acknowledgments}

The present study was supported by the Council of Agriculture under Grants 88-AST-1.4-FID-02(2) and 89-ST-1.2-FA-04(13).

\section{References}

Chang P.S., Wang Y.C., Lo C.F., Kou G.H. \& Chen S.N. (1992) Purification and biochemical characteristics of occlusion body of Penaeus monodon-type baculovirus (MBV). Fish Pathology 27, 127-130.

Chang P.S., Tsai D.H. \& Wang Y.C. (1998) Development and evaluation of a dot blot analysis for the detection of white spot syndrome baculovirus (WSBV) in Penaeus monodon. Fish Pathology 33, 45-52.

Chen S.N. (1995) Current status of shrimp aquaculture in Taiwan. In: Swimming Through Troubled Water. Proceedings of the Special Session on Shrimp Farming. Aquaculture'95 (ed. by C.L. Browdy \& J.S. Hopkins), pp. 29-34. World Aquaculture Society, Baton Rouge, LA, USA.

Chou H.Y., Huang C.Y., Wang C.H., Chiang H.C. \& Lo C.F. (1995) Pathogenicity of a baculovirus infection causing white spot syndrome in cultured penaeid shrimp in Taiwan. Diseases of Aquatic Organisms 23, 165-173.

Durand S., Lightner D.V., Nunan L.M., Redman R.M., Mrai J. \& Bonami J.R. (1996) Application of gene probes as diagnostic tools for white spot baculovirus (WSBV) of penaeid shrimp. Diseases of Aquatic Organisms 27, 59-66.

Flegel T.W. \& Alday-Sanz V. (1998) The crisis in Asian shrimp aquaculture: current status and future needs. Journal of Applied Ichthyology 14, 269-273.

Hameed A.S.S., Anilkumar M., Raj M.A.S. \& Jayaraman K. (1998) Studies on the pathogenicity of systemic ectodermal and mesodermal baculovirus and its detection in shrimp by immunological methods. Aquaculture 160, 31-45.

Inouye K., Miwa S., Oseko N., Nakano H., Kumura T., Momoyama K. \& Hiraoka M. (1994) Mass mortalities of cultured kruma shrimp Penaeus japonicus in Japan in 1993 electron microscopic evidence of the causative virus. Fish Pathology 29, 149-158.

Kanchanaphum P., Wongteerasupaya C., Sitidilokratana N., Boonsaeng V., Panyim S., Tassanakajon A., Withyachumnarnkul B. \& Flegel T.W. (1998) Experimental transmission of white spot syndrome virus (WSSV) from crabs to shrimp Penaeus monodon. Diseases of Aquatic Organisms 34, $1-7$.

Kimura T., Yamano K., Nakano H., Momoyama K., Hiraoka M. \& Inouye K. (1996) Detection of penaeid rod-shaped DNA virus (PRDV) by PCR. Fish Pathology 31, 93-98.

Laemmli U.K. (1970) Cleavage of structural proteins during the assembly of the head of bacteriophage T4. Nature 227, 680-685.

Lo C.F., Ho C.H., Peng S.E., Chen C.H., Hsu H.C., Chiu Y.L., Chang C.F., Liu K.F., Su M.S., Wang C.H. \& Kou G.H. (1996a) White spot syndrome baculovirus (WSBV) detected in cultured and captured shrimp, crabs and other arthropods. Diseases of Aquatic Organisms 27, 215-225.

Lo C.F., Leu J.H., Ho C.H., Chen C.H., Peng S.E., Chen Y.T. \& Chou C.M. (1996b) Detection of baculovirus associated with white spot syndrome (WSBV) in penaeid shrimps using polymerase chain reaction. Diseases of Aquatic Organisms 25, 133-141.

Lo C.F., Hsu H.C., Tsai M.F., Ho C.H., Peng S.E., Kou G.H. \& Lightner D.V. (1999) Specific genomic DNA fragment analysis of different geographical clinical samples of shrimp white spot syndrome virus. Diseases of Aquatic Organisms 35, 175-185.

Nadala E.C.B. Jr \& Loh P.C. (1998) A comparative study of three different isolates of white spot virus. Diseases of Aquatic Organisms 33, 231-234.

Nadala Jr E.C.B., Tapay L.M., Cao S. \& Loh P.C. (1997) Detection of yellow head virus and Chinese baculovirus in penaeid shrimp by the Western blot technique. Journal of Virological Methods 69, 39-44.

Nadala Jr E.C.B., Tapay L.M. \& Loh P.C. (1998) Characterization of a non-occluded baculovirus -like agent pathogenic to penaeid shrimp. Diseases of Aquatic Organisms 33, 221-229.

Nunan L.M., Poulos B.T. \& Lightner D.V. (1998) The detection of white spot syndrome virus (WSSV) and yellow head virus (YHV) in imported commodity shrimp. Aquaculture 160, 19-30.

Takahashi Y., Itami T., Maeda M., Suzuki N., Kasornchandra J., Supamattaya K., Khongpradit R., Boonyaratpalin S., Kondo M., Kawai K., Kusuda R., Hirono I. \& Aoki T. (1996) Polymerase chain reaction (PCR) amplification of bacilliform virus (RV-PJ) DNA in Penaeus japonicus Bate and systemic ectodermal and mesodermal baculovirus (SEMBV) DNA in Penaeus monodon Fabricius. Journal of Fish Diseases 19, 399-403.

van Hulten M.C.W., Westenberg M., Goodall S.D. \& Vlak J.M. (2000) Identification of two major virion protein genes of white spot syndrome virus of shrimp. Virology 266, 227-236.

Wang C.S., Tsai Y.J., Kou G.H. \& Chen S.N. (1997) Detection of white spot disease virus infection in wild-caught greasy back shrimp, Metapenaues ensis (de Haan) in Taiwan. Fish Pathology 32, 35-41.

Wang Q., Poulos B.T. \& Lightner D.V. (2000) Protein analysis of geographic isolates of shrimp white spot syndrome virus. Archives of Virology 145, 263-274.

Zhan W.B., Yu K.K. \& Meng Q.X. (1995) Study on baculovirus disease of Penaeus chinensis. Journal of Fishery Science of China 2, 22-28.

Zhan W.B., Wang Y.H., Fryer J.L., Okubo K., Fukuda H., Yu K.K. \& Meng Q.X. (1999) Production of monoclonal antibodies (MAbs) against white spot syndrome virus (WSSV). Journal of Aquatic Animal Health 11, 17-22.

Received 11 October 2000

Accepted 15 December 2000 